\title{
US tries to stem antimicrobial resistance
}

$\mathrm{D}$ escribing the rise of antibioticresistant bacteria as "a serious threat to public health and the economy," United States President Barack Obama has launched a government-wide "strategic, coordinated and sustained effort" to tackle a problem US officials have linked to two million illnesses and 23000 deaths annually in that country.

Obama identified the fight against antibiotic-resistant bacteria as "a national security priority," and has created the Presidential Advisory Council on Combating Antibiotic-Resistant Bacteria and the Task Force for Combating AntibioticResistant Bacteria, which is co-chaired by the secretaries of defense, agriculture and health.

The task force will draft a five-year National Action Plan by mid-February 2015. Meanwhile, Obama has ordered federal agencies to step up efforts in surveillance, antibiotic stewardship and new drug development, and to collaborate with the WHO in developing a global action plan for antimicrobial resistance.

Obama's initiatives largely flow from two forceful federal reports, notes Amanda Jezek, vice president of public policy and government relations for the Infectious Diseases Society of America, which represents 10000 infectious disease specialists in the US and abroad.

In a September 2013 report on antibiotic resistance threats, the US Centers for Disease Control warned that "up to 50 percent of all the antibiotics prescribed for people are not needed or are not prescribed appropriately." A September 2014 follow-up Report to the President on Combating Antibiotic Resistance by the President's Council of Advisors on Science and Technology reinforced the need for federal leadership, says Jezek.

Jonathan Kaplan, director of the Food and Agriculture Program for the Natural Resources Defense Council, a New York-based environmental group, also welcomed Obama's decision to "elevate this issue as a national priority." But Kaplan says he's disappointed the Food and Drug Agency (FDA) isn't adopting tougher measures against the use of antibiotics to prevent rather than to treat animal diseases. On Oct. 2, the

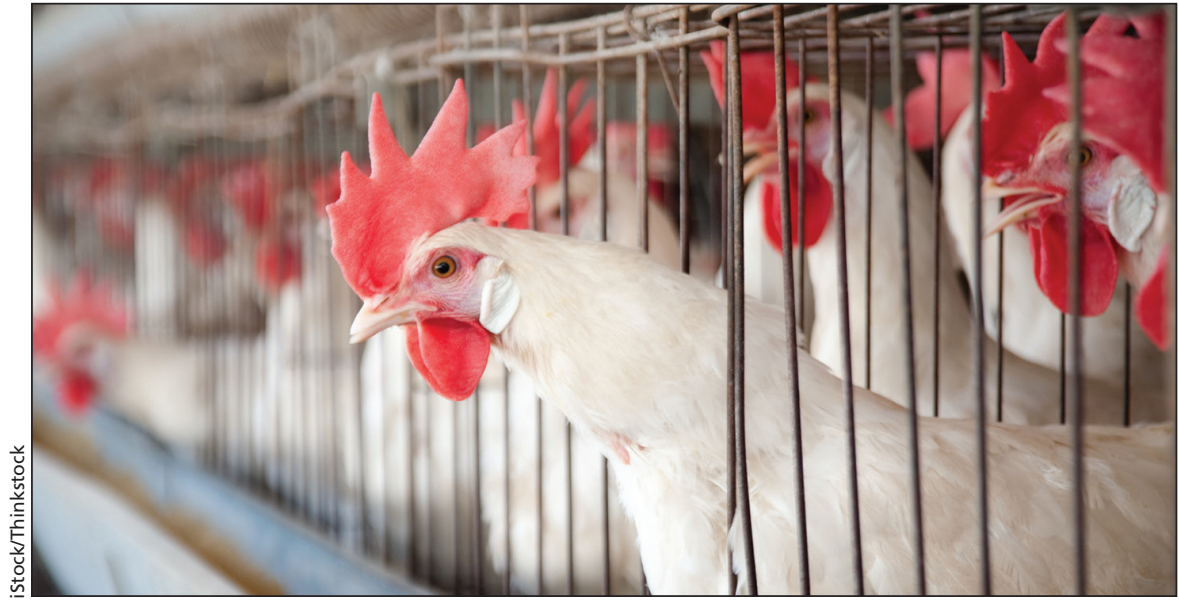

A new US Food and Drug Administration report finds that the use of medically important antibiotics for meat production increased by $16 \%$ from 2009 to 2012 .

FDA revealed that the use of medically important antibiotics for meat production grew by $16 \%$ from 2009 to 2012 . Cephalosporin use increased $37 \%$ in this period, including an $8 \%$ rise in 2012 despite restrictions imposed that year. "I worry we may see business as usual in the pharmaceutical and agricultural industries," says Kaplan.

Efforts similar to those in the US are also underway in the UK, which adopted a national antimicrobial resistance strategy in 2013 and is slated to release an action plan in November. "The issue is finally getting traction internationally," says Ramanan Laxminarayan, director of the Washington-based Center for Disease Dynamics, Economics \& Policy.

\section{Canadian report}

Canadian antibiotic resistance experts have long pressed Ottawa to mount a more concerted federal response. A June 2014 report, Surveillance of Antimicrobial Resistance and Antimicrobial Utilization in Canada, written by the Association of Medical Microbiology and Infectious Disease Canada (AMMI) and published by the National Collaborating Centre for Infectious Diseases (NCCID) warns that Canadian surveillance systems "do not track evolving [antimicrobial resistance] in the community or hospital and thus cannot support development of meaningful responses through better stewardship of antimicrobial use in community or hospital settings, or in veterinary and in food animal production."
Lead author Dr. Lynora Saxinger, chair of the AMMI's Antimicrobial Stewardship and Resistance Committee, says stronger federal leadership is long overdue. The report strongly recommended creating an office for antimicrobial resistance within the Public Health Agency of Canada. But in the published report, that recommendation was relegated to a publisher's note.

"The NCCID does not have a mandate to recommend specific policy or to advocate for specific government actions," explains Dr. Joel Kettner, the Centre's scientific director.

Dr. Michael Mulvey, chief of Antimicrobial Resistance and Nosocomial Infections at the National Microbiology Laboratory in Winnipeg, says federal surveillance of hospital-based antimicrobial resistance as well as drug resistance from "farm to fork" is "fairly robust." Although acknowledging that the AMMI report accurately reveals a major gap in national surveillance of communitybased resistance, especially for emerging highly drug-resistant pathogens such as carbapenem-resistant strains, Mulvey says Canada has "one of the better surveillance systems in the world today." Substantial improvements in federal coordination of surveillance such as those recommended by AMMI are "not beyond our capacity," Mulvey acknowledges. "We're taking that report very seriously." - Paul Webster, Toronto, Ont.

CMAJ 2014. DOI:10.1503/cmaj.109-4917 